\title{
TORTS: NEW APPROACH SUGGESTED IN HOLDING GUEST STATUTES INAPPLICABLE
}

Automoвile guest statutes ${ }^{1}$ relieve motorists from common law liability $^{2}$ for ordinary negligence when the plaintiff is carried as a guest without payment ${ }^{3}$ for such transportation. These statutes subvert a prevailing policy in the law of torts-that of spreading the risk of loss from personal tragedies ${ }^{4}$-and have been narrowly construed ${ }^{5}$ In Truitt v. Gaines ${ }^{b}$ the Third Circuit Court of Appeals further reduced the scope of the Delaware guest statute ${ }^{7}$ by extending the legal definition of "payment" and by suggesting that the payment test is not the only means of preventing the application of the enactments.

The suit arose as a result of injuries suffered by a student and his mother in an automobile accident which occured on the way home from a visit to a doctor's office. The defendant was a teacher at the boy's school who, at the mother's request and without promise or suggestion of remuneration, had agreed to provide the transportation. Defendant appealed the district court decision for the plaintiffs, alleging that the lower tribunal had erred in failing to find that the plaintiffs were guests. The circuit court affirmed, reasoning that

\footnotetext{
1 Passed primarily in the 1930's the statutes originally applied to automobiles, but have been extended in many states to cover other motor vehicles. There are twentyseven states in which the guest statutes are presently in effect. See Automobile Guest Laws Today; Report of the Automobile Insurance Committee-1960, 27 INs. Counser J. 223 (1960) (listing the states and summarizing the statutory provisions).

In the absence of guest statutes the driver in all but a few jurisdictions is bound to use reasonable and ordinary care for the safety of his guest. See, e.g., Sullivan v. LeBlanc, 100 N.H. 3I1, 125 A.2d 652 (1956); Spivey v. Newman, 232 N.C. 281, 59 S.E.2d 844 (1950). Contra, Caskey v. Underwood, 89 Ga. App. 4I8, 79 S.E.2d 558 (1953); Massaletti v. Fitzroy, 228 Mass. 487, 118 N.E. 168 (I917) (analogizing driver to gratuitous bailee of chattels).

${ }^{3}$ The two major classes of guest statutes require the absence of (1) payment or (2) compensation for the statute to apply. See Georgetta, The Major Issures in a Guest Case, 1954 Ins. L.J. 583.

- Prosser, Torts 19 (2d ed. 1955). Guest statutes also cut across the trend toward doing away with degrees of care. 2 HARPER \& JAMES, TORTS 961 (1956).

- See cases cited note 14 infra and accompanying text.

- 318 F.2d 461 (3d Cir. 1963), affirming 199 F. Supp. I43 (D. Del. 1961).

7 "No person transported by the owner or operator of a motor vehicle, boat, airplane, or other vehicle as his guest without payment for such transportation shall have a cause of action for damages against such owner or operator for injury, death or loss, in case of accident, unless such accident was intentional ... or was caused by his wilful or wanton disregard of the rights of others." DEL. CODE ANN. tit. 21, $\$ 6101$ (a) (1953). (Emphasis added.)
} 
the defendant had derived from the trip a tangible and substantial benefit relating to his profession. ${ }^{8}$

Guest statutes were designed to protect the public from the abuses of vexacious and collusive suits. ${ }^{9}$ Their passage was also motivated by a desire to protect generous motorists in cases of slight deviation from the normal standard of care. ${ }^{10}$ Advocates of the latter justification advanced the proverbial analogy of "preventing the dog from biting the hand that feeds it."11 Since the language of the statutes is broad ${ }^{12}$ and the penalty harsh, ${ }^{13}$ the judiciary, by utilization of the principle of strictly construing statutes in derogation of the common law, has attempted to limit enforcement to correction of the evils at which the legislation was aimed.14

The plaintiff is barred in suits complaining of ordinary negligence if he is ruled a "guest" and is not barred if found to be a "passenger."15 The earliest decisions considered the plaintiff a

${ }^{8} \mathrm{~A}$ three member minority disagreed with the district court's fact-finding that a benefit was conferred on defendant. This minority contended that even if the de* fendant believed he was benefiting himself in furtherance of his profession, it was the kind of intangible benefit which is not payment. $318 \mathrm{~F} .2 \mathrm{~d}$ at 466.67 (dissent).

- See Silver v. Silver, 280 U.S. 117 (1929) (guest statutes held valid against challenge to constitutionality).

Numerous inequitable recoveries would be harmful to the public interest since they would probably be reflected in the community liability rates. See Naudzius v. Lahr, 253 Mich. 216, 224, 234 N.W. 581, 584 (1931). One author questions whether the guest statutes have had any real effect on casualty insurance rates. Tipton, Florida's Automobile Guest Statute, 11 U. FLA. L. REv. 287, 305 (1958).

${ }^{10}$ See Weber, Guest Statutes, 11 U. Cinc. L. Rev. 24 (1937); 19 CiII.-KeNT L. REv. 281 (1941).

${ }^{11}$ See Crawford v. Foster, 110 Cal. App. 81, 87, 293 Pac. 841, 843 (Dist. Ct. App. 1930); Chaplowe v. Powsner, 119 Conn. 188, 190, 175 Atl. 470, 471 (1934).

${ }_{12}$ The first guest statute, passed in Connecticut in 1927 was drafted by nonlawyers and passed without study by the state legislative judiciary committec. Yet the far-reaching wording used therein was adopted by substantially all the states that maintain the enactments. In 1937 Connecticut repealed the original statute over the governor's veto. Sce Tipton supra note 9 , at 288.

${ }^{13}$ It seems that one may more readily grasp the harshness of the law by vicwing the plaintiff as abandoning his cause of action in consideration for the free ride. Had the cause of action accrued prior to the offer and acceptance of the ride, it is doubtful whether any court would uphold such a contract as a valid settlement.

If fear of collusion is the reason for the statutes, then the innocent are punished along with the guilty. 41 ORE. L. REv. 133 (1962).

14 Arkansas Valley Co-op. Rural Elcc. Co. v. Elkins, 200 Ark. 883, 141 S.W.2d 538 (1940); Hunter v. Baldwin, 268 Micl. 106, 255 N.W. 431 (1934); Smith v. Clute, 227 N.Y. 407, 14 N.E.2d 455 (1938). Contra, Nielsen v. Kohlstedt, 117 N.W.2d 900 (lowa 1962) (statute should be literally construed in order to effectuate its purpose).

15 The status of guest is a question of fact for the jury if the whole evidence leaves the issue in doubt. 2 HARPER \& JaMEs, TorTs 961 (1956). However, as there is often little controversy as to the facts, in practice the judge is frequently required to rule as to the plaintiff's status. 
passenger only when the host was directly ${ }^{16}$ compensated for the ride or was acting within his contractual duties in supplying the transportation. ${ }^{17}$ The passage of time saw a growing recognition that substantial contribution towards motoring expense, ${ }^{18}$ assistance in driving, ${ }^{19}$ promises of reciprocal rides $^{20}$ and similar non-contractual obligations ${ }^{21}$ assumed by the rider are tangible benefits sufficient to satisfy the payment requirement. On the other hand, incidental benefits such as companionship remained consistent with the status of guest. ${ }^{22}$

An additional development occurred in employment-related cases where the parties stood in the relation of buyer and seller, ${ }^{23}$ or principal and agent. ${ }^{24}$ The definition of payment was enlarged by these cases to include the prospective pecuniary advantage made available to the driver through his providing transportation. The court has seemingly extended that rationale in the principal case. It noted that the offer of a ride was employment connected and then

${ }^{10}$ It was not necessary, however, that the consideration flow from the passenger to the driver. See Elliot v. Behner, $146 \mathrm{Kan}$. 827, 73 P.2d 1116 (1937); McGuire v. Armstrong, 268 Mich. 152, 255 N.W. 745 (1934). If the occupant did not pay for the transportation then he must be one of a class for whose carriage the driver is being compensated. His status may be analyzed by the principle of third party beneficiary contracts. Weber, supra note 10 , at 42 .

${ }^{27}$ Accord, Casper v. Higgins, 54 Ohio App. 21, 6 N.E.2d 3 (1935); Schiltz v. Picton 66 S.D. 301,282 N.W. 519 (1938). In both cases plaintiffs were students and defendants escaped liability by showing that providing the transportation was not a contractual obligation. The Ohio court held that plaintiff was a guest, although defendant-teacher was reimbursed by the university for his expenses and the enterprise was considered a part of the duties for which he received his regular salary, by reasoning that the instructor was not contractually required to make the trip. Casper v. Higgins, supra at 25, 6 N.E.2d at 6.

${ }^{18}$ Kerstetter v. Elfman, $327 \mathrm{~Pa} .17,192$ Atl. 663 (1937) (applying Delaware statute); Annot., 10 A.L.R.2d 1351, 1373 (1950). In cases of expense sharing the status of the occupant has depended upon whether there was a pre-arranged contract for the transportation. See 27 VA. L. REv. 559 (1941). Compare Asmuth v. Kemper, 174 A.2d 820 (Del. 1961), with Wilkes v. Melice, 48 Del. (9 Terry) 206, 100 A.2d 742 (1953).

${ }^{10}$ See Duncan v. Hutchinson, 139 Ohio St. 185, 39 N.E.2d 140 (1942); Scholz v. Leuer, 7 Wash. 2d 76, 109 P.2d 294 (1941); Annot., 10 A.L.R.2d 1351, 1361 (1950).

${ }^{20}$ See Baynes v. McElrath, 106 Ga. App. 805, 128 S.E.2d 348 (1962); Gilliland v. Singleton, 204 Va. 115, 129 S.E.2d 641 (1963).

${ }_{21}$ See Simms v. Tingle, 232 Ark. 239, 335 S.W.2d 449 (1960) (church stamp drive); Thuente v. Hart Motors, 234 Iowa 1294, 15 N.W.2d 622 (1944); Delk v. Young, 33 Ohio L. Abs. 508, 35 N.E.2d 969 (Gt. App. 1941) (political campaign for defendant as candidate). But see England v. Stauffer, 145 So. 2d 545 (Fla. Dist. Ct. App. 1962).

${ }^{23}$ See Whitechat v. Guyette, 19 Cal. 2d 428, 122 P.2d 47 (1942); Boyd v. Mueller, 320 IIl. App. 303, 50 N.E.2d 847 (1943).

${ }^{28}$ See Robb v. Ramey Associates, 40 Del. (1 Terry) 520, 14 A.2d 394 (Super. Ct. 1940); Luebke v. Hawthorne, 183 Ore. 362, 192 P.2d 990 (1948).

24 See McBee v. Knight, 377 P.2d 163 (Ore, 1962); Dunn v. Stumbers, 174 A.2d 567 (Del. Super. Ct. 196I); 51 Harv. L. REv. 545 (1938). 
found the necessary benefit in furtherance of defendant's professional duties and responsibilities. However, it was not contended that defendant was obligated by his contract to provide the service rendered, nor was there evidence that by his action he would have earned a profit or salary increase. Nonetheless, the trial court decided and the appellate court affirmed that "in helping the Truitts he was earning his salary.... and establishing his availability for larger responsibility ...."25

To understand this decision it is essential to view the changing policy considerations in the field of automobile torts. It is now questionable whether one of the objects of guest statutes-that of maintaining a legislated sense of fairness between generous hosts and unappreciative guests-is still meaningful. With the increasing number of injury-causing accidents, ${ }^{26}$ uninsured drivers are in disfavor with the law and should not be the object of benevolent protection. ${ }^{27}$ An insured driver is not particularly concerned with suits instituted against him by his riders. ${ }^{28}$ To extend this defense to an insurance company that has performed no service for which the guest has reason to be appreciative would be illogical unless realistic support can be found in the fear of collusion. ${ }^{20}$ It would seem then that the issue in guest cases ought to be: how great is the fear of collusion? ${ }^{30}$

$25318 \mathrm{~F} .2 \mathrm{~d}$ at 465 .

${ }^{20}$ Motor vehicle accidents resulted in 38,200 deaths, 120,000 permanent impairments, and 1,280,000 temporary total disabilities in the year of 1960 alone. 1962 World Almanac 303.

${ }^{27} 54$ Nw. U.L. REv. 263, 271 (1959); cf. Ward, The Uninsured Motorist: National and International Protection Presently Available and Comparative Problems in Sub. stantial Similarity, 9 Buffalo L. Rev. 283 (1960); Comment, 48 Calif. L. Rev. 516 (1960).

${ }^{28}$ The driver's own liability rates should not be affected by the availability of this technical defense. See generally PATterson, Insurance 226 (2d ed. 1957).

${ }^{20}$ That fear arises because the defendant driver, knowing that he is protected by indemnification, arguably would not be adverse to admitting non-existent negligence. But cf. La Chance v. Service Trucking Co., 215 F. Supp. 162 (D. Md. 1963), where the court allowed a third party complaint for contribution against the plaintiff's husband although the law of Maryland did not permit the wife to prosecute actions based on her husband's negligence. Working through a conflict of laws concept the court avoided the Maryland law by noting that the public policy behind it-preventing collusive suits against the husband's insurer-did not apply in this case. Similarly it can be said that in multi-car collisions a motorist will not lightly admit negligence as to guests because in doing so he might prejudice his rights against the other parties. Few one-car accidents would seem to occur without negligence by the driver.

so Actual collusion in the particular case is a separate issue. If collusion can be proved the plaintiff will be barred. Guest statutes, on the other hand, show a legislative coguizance of the difficulty in finding cooperation between adverse parties. Where 
The case law indicates that the judiciary has interpreted payment in a manner mindful of barring recovery when the fear of collusion is greatest. When the trip was primarily social, as in situations where the plaintiff and the defendant are close friends ${ }^{\mathbf{3 1}}$ or relatives ${ }^{32}$ even monetary benefits have sometimes been held insufficient to exclude the guest relationship. Whereas when the occasion for the trip arose in a business context, payment has not been interpreted in a strict sense and many courts have permitted recovery. ${ }^{33}$

The distinction between social situations and those where the plaintiff is not a social guest ${ }^{34}$ is reached by looking to the intention of the parties to determine whether the benefit received was the motivating cause for which the driver furnished the transportation. ${ }^{35}$ The decision in the principal case does not rely on this motivation test, but instead the majority opinion considers it sufficient that the defendant's action was the result of complex and intermingling forces, and not solely for humanitarian purposes. It would be a logical extension of this decision to prevent a local businessman from applying the statutory defense against practically anyone. The reasoning could be that any assistance given the plaintiff was inspired by complex motives, at least one of which was the desire to gain the good will of the passenger.

An explanation of this holding which finds payment when there was none in the ordinary sense of the word, appears in a footnote $e^{36}$ to the case in which Judge McLaughlin, the author of the majority

the fear of such cooperation is justified, it would be in accordance with the legislative intent to bar the claimant.

${ }^{31}$ See Wagnon v. Patterson, 260 Ala. 297, 70 So. 2d 244 (1954); Mears v. Kovacic, 381 P.2d 991 (Colo. 1963).

${ }^{32}$ Smith v. Franklin, 14 Utah 2d 16, 376 P.2d 541 (1962); see Hasbrook v. Wingate, 152 Ohio St. 50, 87 N.E.2d 87 (1949); Hough v. McMillan, 351 S.W.2d 609 (Tex. Civ. App. 1961) (relationship by marriage raises presumption against compensation); 10 U. PITT. L. REv. 591 (1949).

${ }^{33}$ See Liberty Mut. Ins. Co. v. Stitzle, 220 Ind. 180, 41 N.E.2d 133 (1942); McBee v. Knight, 377 P.2d 163 (Ore. 1962); 9 U. FLA. L. REv. 232 (1956). But see McGowan v. Wilson, 154 So. $2 d 331$ (Fla. Dist. Ct. App. 1963); Matlock v. L. A. Hooge Co., 365 S.W.2d 386 (Tex. Civ. App. 1963).

3s The Ohio Supreme Court has formulated a list of criteria for determining whether a trip is business or social: (1) the nature of the relations between the parties; (2) the object of the trip; (3) isolated instance or permanent activity; (4) whether or not based on contract; (5) the nature and adequacy of the payment. 8 CLEv.-MAR. I. REv. 279, 290 (1959); see Miller v. Fairley, 141 Ohio St. 327, 48 N.E.2d 217 (1943).

${ }^{30}$ See Wills v. Buchanan, 358 S.W.2d 727 (Tex. Civ. App. 1962); 15 ARk. L. Rev. 204 (1961); cf. 41 ORE. L. REv. 133 (1962) (adoption of a statutory motivation test).

${ }^{30} 318$ F.2d at 465 n.3. 
opinion, states: "Glosely interrelated to the fact that the presence of 'payment' renders the statute inapplicable is the second and independent requirement that the claimant must not be a 'guest'...." (Emphasis added.) Since the question of whether the rider was a passenger or guest had been traditionally determined solely on the presence or absence of payment to the driver, ${ }^{37}$ the McLaughlin test represents a novel approach to guest statute problems. ${ }^{38}$ In accord with this test two questions must be answered in the negative before declaring that the party was a guest: (1) Was there payment?

Did the occasion for the trip arise in other than the normal host-guest relationship?39 The force of logic is behind the McLaughlin distinction since where the plaintiff is not a usual recipient of the hospitality of the defendant, but a mere acquaintance or business associate, the fear of collusion is not so pressing as to necessitate the abrogation of the right to recover for negligent harm inflicted.

As the penalty of guest statutes is strict and the policy justification questionable, it is proper that the bar be allowed as a defense only when the reasoning of the law clearly calls for its application. It was not clear in the principal case that the relationship between the parties involved any particular prospects of collusion. The judicial process has more discriminating methods of sifting out fraud in litigation than by barring the cause of action completely. ${ }^{40}$ In that regard, the seemingly awkward manipulation of the payment concept in Truitt is useful in that it reaches an equitable result. However, an articulation of the McLaughlin dictum as a clear holding in the main body of the decision would have been preferable as such a precedent would provide the judiciary with a more meaningful method of weighing the policy of mitigating the effects of personal injuries against the evils of unjust recoveries.

\footnotetext{
${ }^{87}$ See Follansbee v. Benzenberg, 122 Cal. App. 2d 466, 265 P.2d 183 (App. Div. 1954).

${ }^{38}$ The issue of guest status aside from the question of payment has arisen in differ. ent contexts. Cf. Andrews v. Kirk, 106 So. 2d 110 (Fla. Dist. Ct. App. 1958) (involuntary rider); Horst v. Holtzen, 249 Iowa 958, 90 N.W.2d 41 (1958) (infant as guest).

${ }^{80}$ Thus, no payment plus a guest-host relationship means that the plaintiff would be a guest within the statute. Cf. Yarnell, Guest Without Payment for Such Transportation, 29 MAN. B. NEws 81 (1957) (adoption of a similar test in a Canadian juris. diction).

to Statutes of this type show little confidence in the honesty of plaintiff attorneys, the ability of defense attorneys to cross-examine, and/or the wisdom of local jurors.
} 